\title{
Ongoing airway inflammation in patients with COPD who do not currently smoke
}

Steven R Rutgers, Dirkje S Postma, Nick H T ten Hacken, Henk F Kauffman, Thomas W van der Mark, Gerard H Koëter, Wim Timens

\begin{abstract}
Background-Inflammatory changes in the airways in chronic obstructive pulmonary disease (COPD) are largely attributed to smoking, yet they may be present even if patients do not currently smoke. The differences in inflammatory cells and the factors contributing to these differences were examined in the airways of patients with COPD who do not currently smoke.
\end{abstract}

Methods-Eighteen non-atopic subjects with COPD (14 men) of mean (SD) age 62 (8) years and forced expiratory volume in one second $\left(\mathrm{FEV}_{1}\right) 59(13) \%$ predicted and 11 non-atopic healthy subjects (eight men) of mean (SD) age 58 (8) years, FEV $_{1} 104$ (11)\% predicted were studied. Sputum induction and bronchoscopy with bronchoalveolar lavage (BAL) and biopsies were performed.

Results-Patients with COPD had more mucosal EG2+ cells (eosinophils) (median (range) $40(0-190)$ versus $5(0-40)$ cells/ $\left.\mathrm{mm}^{2}, \mathrm{p}=0.049\right)$ and CD68+ cells (1115 (330-2920) versus $590(450-1580)$ cells/ $\mathbf{m m}^{2}, \mathbf{p}=0.03$ ), and a tendency towards more CD4+ but not CD8+ lymphocytes than healthy controls. Furthermore, patients with COPD had higher percentages of sputum neutrophils (77 (29-94) versus $36(18-60) \%, p=0.001)$ and eosinophils (1.2 (0-8.5) versus $0.2(0-3.1) \%, p=0.008)$, BAL fluid eosinophils $(0.4(0-1.7)$ versus $0.2(0-0.5) \%, p=0.03)$, and higher concentrations of sputum eosinophilic cationic protein (ECP) (838 (115-23 760) versus 121 (35-218) ng/ml, p<0.001). Concentrations of ECP expressed per eosinophil were not higher. Patients with COPD with high mucosal EG2+ cell numbers also had high mucosal CD4+ cell numbers. Sputum eosinophilia was associated with a decrease in $\mathrm{FEV}_{1} / \mathrm{VC}$ and BAL fluid eosinophilia with a decrease in mucosal NP57+ cells (neutrophils).

Conclusions-Subjects with COPD who do not currently smoke have increased numbers of inflammatory cells. Eosinophils are increased in number in the airways in COPD but do not seem to be activated. The increased eosinophil numbers are probably due to recruitment as a result of ongoing inflammation. Macrophages and lymphocytes may play a part in this inflammation.

(Thorax 2000;55:12-18)
Keywords: chronic obstructive pulmonary disease; biopsy; inflammation

Chronic obstructive pulmonary disease (COPD) is a slowly progressive disease clinically characterised by shortness of breath, cough, mucus production, and/or wheezing. ${ }^{1}$ Inflammatory changes in both airways and lung parenchyma may contribute to the presence of symptoms. ${ }^{2}$ Airway inflammation is often present in COPD and has received considerable attention in recent years by studies on the relation between these inflammatory changes and the pathophysiology of COPD. ${ }^{4-7}$

In bronchial biopsy specimens the inflammatory changes in the mucosa in COPD have been recognised to constitute increased numbers of macrophages and activated, predominantly CD8+, T cells. ${ }^{5-10}$ Eosinophil numbers are increased during exacerbations and possibly also during a stable phase of the disease in a subset of patients. ${ }^{41}$ Mast cell numbers are not increased in the mucosa ${ }^{2}$ yet increased numbers of mast cells have been found in bronchial glands of patients with chronic bronchitis. $^{12}$

In bronchoalveolar lavage (BAL) fluid macrophages are mainly found, followed by increased neutrophil and eosinophil numbers. ${ }^{4}$ In induced sputum neutrophils predominate, ${ }^{13}$ and eosinophil numbers and the concentration of eosinophilic cationic protein (ECP) may also be increased..$^{14}$ Neutrophils and activated eosinophils are attracted to the airway lumen by several chemotactic cytokines such as interleukin 8 (IL-8) which can be produced by various cells including epithelial cells and neutrophils. ${ }^{16}$

It is well known that considerable overlap exists between subjects with COPD and healthy subjects with regard to differences in cell numbers and mediators in biopsy specimens, sputum, and BAL fluid. ${ }^{458}{ }^{9}$ However, it has not yet been established which factors in COPD contribute to the occurrence of inflammatory cell numbers and mediator values that are out of the ranges observed in healthy individuals. The knowledge of these factors may contribute to our further understanding of the pathophysiology of COPD.

In the current study we assessed the differences in inflammatory parameters between subjects with COPD and healthy individuals. We then focused on these factors and investigated the differences in clinical and inflammatory parameters between patients with COPD in whom these factors were out of the range of healthy individuals and compared 
them with the remainder of the patients. We studied these factors in biopsy specimens, induced sputum, and BAL fluid in subjects with COPD and healthy subjects. Since current smoking may influence numbers of airway inflammatory cells and affect $T$ cell subset proportions, ${ }^{17-19}$ we only selected subjects with COPD who did not currently smoke and matched these subjects with healthy controls for age and pack years.

\section{Methods \\ SUBJECTS}

Subjects were recruited from the pulmonary outpatient clinic of the Groningen University Hospital and by advertisements in local newspapers. Twenty subjects with COPD, according to American Thoracic Society (ATS) criteria, ${ }^{20}$ and 12 healthy control subjects participated in the study. Subjects with COPD had a forced expiratory volume in one second $\left(\mathrm{FEV}_{1}\right)$ and $\mathrm{FEV}_{1}$ /vital capacity $(\mathrm{VC})<$ predicted value -1.64 residual standard deviation $^{21}$ and an increase in $\mathrm{FEV}_{1}$ predicted of $<10 \%$ after inhalation of $1 \mathrm{mg}$ terbutaline via a Turbohaler. Four subjects with COPD were never smokers, all other participants were ex-smokers - that is, they had quit smoking at least one year before the start of the study. Sixteen subjects with COPD had chronic bronchitis according to ATS criteria. ${ }^{20}$ All subjects had a negative history of atopy, negative skin tests to 18 common aeroallergens (ALK, Groningen, The Netherlands), and negative specific serum IgE for 11 common aeroallergens (Phadiatop). Thirteen subjects who had maintenance treatment with inhaled corticosteroids discontinued this at least one month prior to the study. Exclusion criteria were treatment with oral corticosteroids and antibiotics or a respiratory tract infection in the month prior to the study. Healthy volunteers did not have a history of pulmonary disease, had normal lung function, were ex-smokers, and were matched for age and pack years.

The protocol was approved by the hospital ethical committee and all subjects gave their written informed consent.

\section{DESIGN OF STUDY}

The study involved three visits. At the first visit the patient's history was taken, physical examination and spirometric tests with an $\mathrm{FEV}_{1}$ reversibility test were performed, and atopy was assessed. At the second visit sputum was induced. At the third visit, 7-14 days after visit 2 , bronchoscopic examination with BAL was performed and biopsy specimens of the bronchial mucosa were taken.

\section{SPIROMETRIC TESTS}

Spirometric tests were performed using a calibrated water sealed spirometer (Lode BV, Groningen, The Netherlands) according to standardised guidelines. ${ }^{21}$ Subjects did not use short acting bronchodilators within 12 hours of the measurements and did not smoke or drink tea or coffee on the morning of the visit.
SPUTUM INDUCTION

Sputum was induced by inhalation of hypertonic saline aerosol, generated by an ultrasonic nebuliser (Ultraneb 2000, DeVilbiss, Somerset, Pennsylvania, USA). The nebuliser was calibrated at an output of $1.5 \mathrm{ml} / \mathrm{min}$ and produced particles with a diameter of $4.5 \mu \mathrm{m}$. Solutions of sodium chloride of $3 \%, 4 \%$ and $5 \%(\mathrm{w} / \mathrm{v})$ were nebulised at room temperature for seven minutes each and administered through a $100 \mathrm{~cm}$ long tube with an internal diameter of $22 \mathrm{~mm}$. Subjects had a noseclip in situ and held their mouth in front of the end of the tube, allowing exhalation beside the tube. Three $\mathrm{FEV}_{1}$ manoeuvres were performed 15 minutes after inhalation of $1 \mathrm{mg}$ terbutaline via a Turbohaler and the highest value was taken as baseline $\mathrm{FEV}_{1}$. Subjects then inhaled the hypertonic saline aerosols. Following each period of hypertonic inhalation subjects were asked to blow their nose and to rinse their mouth and gargle their throat thoroughly with water. They were then encouraged to cough and expectorate sputum into a sterile plastic container which was kept on ice. The procedure was terminated after three periods of seven minutes or after a fall in $\mathrm{FEV}_{1}$ of $20 \%$ or more from the baseline value.

\section{SPUTUM PROCESSING}

Sputum was processed within 15 minutes of termination of the induction. The volume of the whole sputum sample was determined and an equal volume of dithiothreitol $0.1 \%$ (Sputolysin; Calbiochem, La Jolla, California, USA) was added. The samples were vortexed using a wide bore plastic test tube and placed in a shaking water bath at $37^{\circ} \mathrm{C}$ for 15 minutes to ensure complete homogenisation. The samples were then filtered through a $48 \mu \mathrm{m}$ nylon gauze and vortexed, followed by total cell count and viability check by trypan blue exclusion. The filtered sample was centrifuged at $400 \mathrm{~g}$ at $4^{\circ} \mathrm{C}$ for five minutes. The supernatant was aspirated and stored in Eppendorf cups at $-80^{\circ} \mathrm{C}$. The cell pellet was resuspended in $0.5 \%$ bovine serum albumin (BSA) in phosphate buffered saline to a concentration of $0.3 \times 10^{6}$ cells $/ \mathrm{ml}$ and cytospins were made by putting $100 \mu \mathrm{l}$ of the cell suspension in the funnels and centrifuging at $450 \mathrm{~g}$ with low deceleration over five minutes. Two cytospin slides for differential cell counts were stained with May-GrünwaldGiemsa (MGG). The remaining cytospins, to be used for immunocytochemistry, were dried under a cold air blower for one hour, put into a sealed plastic sleeve filled with nitrogen gas, and stored at $-80^{\circ} \mathrm{C}$ until analysis. Differential cell counts were performed by counting 300 non-squamous cells in each coded MGG cytospin in a blind way by two technicians. The mean of the two scores was used for analysis. Absolute cell numbers per $\mathrm{ml}$ sputum were calculated by multiplying the cell percentage with the total (non-squamous) cell number in the sputum, divided by the volume of the sputum sample. 
Table 1 Clinical characteristics of study subjects

\begin{tabular}{lll}
\hline & COPD & Healthy controls \\
\hline M/F & $14 / 4$ & $8 / 3$ \\
Mean (SD) age (years) & $62(8)$ & $58(8)$ \\
Mean (SD) pack years smoking & $28(22)$ & $25(15)$ \\
Mean (SD) years since quitting smoking & $11(12)$ & $15(10)$ \\
Never smoker (n) & 3 & 0 \\
Chronic bronchitis (n) & 14 & 0 \\
Mean (SD) FEV $(\%$ predicted) & $59(13)^{\star}$ & $104(11)$ \\
Mean (SD) $\Delta$ FEV $_{1}(\%$ predicted) & $6(2)$ & $3(3)$ \\
Sputum induction (n) & 18 & 11 \\
Bronchoalveolar lavage (n) & 16 & 11 \\
Bronchial biopsy (n) & 17 & 10 \\
\hline
\end{tabular}

${ }^{\star} \mathrm{p}<0.001$, COPD versus healthy controls.

$\triangle \mathrm{FEV}_{1}$ after inhalation of $1 \mathrm{mg}$ terbutaline.

Table 2 Summary of the significant differences in cellular parameters between patients with COPD and healthy individuals

\begin{tabular}{|c|c|c|c|}
\hline & $C O P D$ & Healthy controls & $p$ value \\
\hline \multicolumn{4}{|l|}{ Biopsy specimen } \\
\hline $\mathrm{EG} 2+\left(\right.$ cells $\left./ \mathrm{mm}^{2}\right)$ & $40(0-190)$ & $5(0-40)$ & 0.049 \\
\hline $\mathrm{CD} 68+\left(\right.$ cells $\left./ \mathrm{mm}^{2}\right)$ & $1115(330-2920)$ & $590(450-1580)$ & 0.03 \\
\hline CD $3+\left(\right.$ cells $\left./ \mathrm{mm}^{2}\right)$ & $935(170-2240)$ & $385(210-1520)$ & 0.07 \\
\hline $\mathrm{CD} 4+\left(\right.$ cells $\left./ \mathrm{mm}^{2}\right)$ & $560(100-1320)$ & $260(60-870)$ & 0.07 \\
\hline \multicolumn{4}{|l|}{ Sputum } \\
\hline Neutrophils (\%) & $77(29-94)$ & $36(18-60)$ & 0.001 \\
\hline Eosinophils (\%) & $1.2(0-8.5)$ & $0.2(0-3.1)$ & 0.008 \\
\hline $\mathrm{IL}-8(\mathrm{ng} / \mathrm{ml})$ & $15.4(3.5-1300)$ & $4.6(3.1-7.7)$ & 0.001 \\
\hline $\mathrm{ECP}(\mathrm{ng} / \mathrm{ml})$ & $838(115-23760)$ & $121(35-218)$ & 0.001 \\
\hline \multicolumn{4}{|l|}{ BAL fluid } \\
\hline Eosinophils (\%) & $0.4(0-1.7)$ & $0.2(0-0.5)$ & 0.03 \\
\hline IL-8 (pg/ml) & $35.8(0-2639)$ & $8.2(0-56.6)$ & 0.06 \\
\hline
\end{tabular}

Data are medians (ranges).

$\mathrm{ECP}=$ eosinophil cationic protein; $\mathrm{IL}=$ interleukin; $\mathrm{BAL}=$ bronchoalveolar lavage .

BRONCHOSCOPIC EXAMINATION

Subjects gargled with $5 \mathrm{ml}$ of $2 \%$ or $4 \%$ lidocaine and had $2 \%$ lidocaine sprayed on the posterior pharynx and dripped onto the vocal cords and into the trachea. The flexible fibreoptic bronchoscope (Olympus B1 IT10, Olympus Optical, Tokyo, Japan) was introduced wedged in a subsegmental bronchus of the middle lobe. Lavage was performed with four $50 \mathrm{ml}$ aliquots of normal saline prewarmed at $37^{\circ} \mathrm{C}$. Each aliquot was immedi-

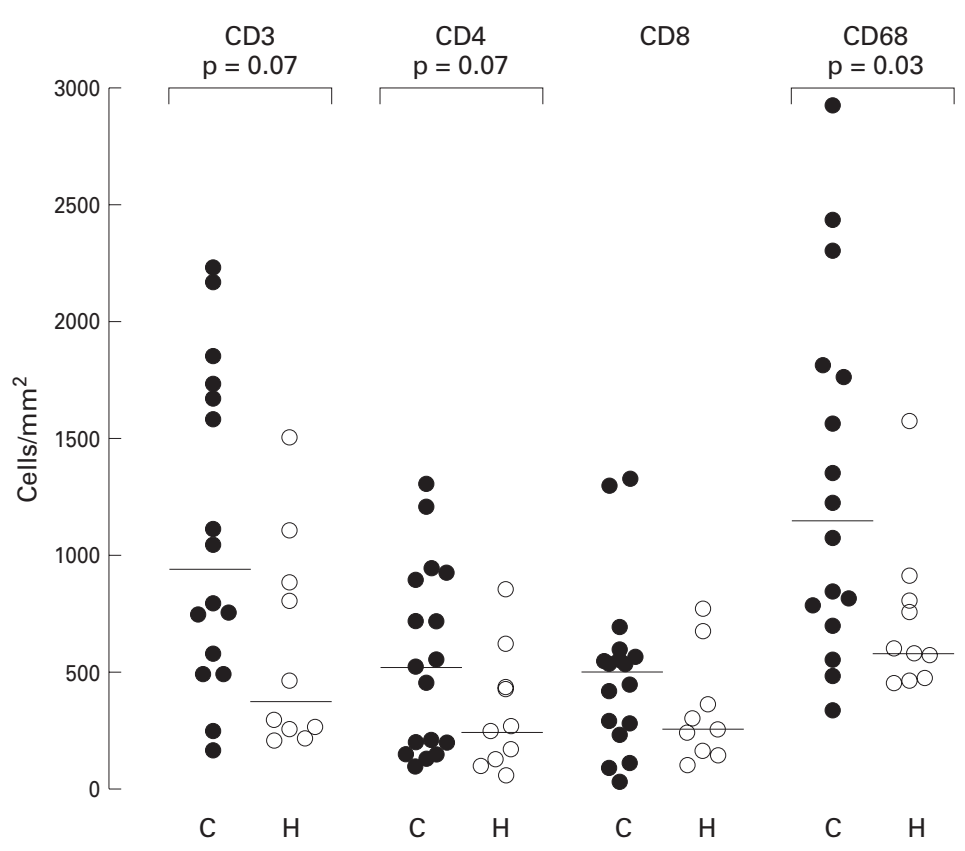

Figure 1 Mucosal lymphocyte and macrophage counts in biopsy specimens from subjects with $\operatorname{COPD}(\mathrm{C}, \bullet)$ and healthy individuals $(\mathrm{H}, \mathrm{O})$. CD3 represents total lymphocyte count, CD4 and CD8 lymphocyte subsets, and CD68 macrophages. ately recovered using a negative pressure of $<20 \mathrm{~mm} \mathrm{Hg}$. The first aliquot was recovered separately and the following three aliquots were pooled and used for analysis. After completion of lavage, bronchial biopsy specimens were taken from subsegmental carinae of the right or left lower lobe using a fenestrated cup forceps (Olympus BF-21C, Tokyo, Japan).

LAVAGE PROCESSING

BAL fluid was placed on ice and processed within 10 minutes after recovery. It was filtered through a $48 \mu \mathrm{m}$ nylon gauze (Curapharm 249.1 filter) and recovery was assessed. The BAL fluid was centrifuged at $400 \mathrm{~g}$ at $4^{\circ} \mathrm{C}$ for five minutes; the supernatant was decanted and stored in Eppendorf cups at $-80^{\circ} \mathrm{C}$. The cell pellet was resuspended in BSA buffer and centrifuged again at $400 \mathrm{~g}$ at $4^{\circ} \mathrm{C}$ for five minutes. The supernatant of the second centrifugation was aspirated and the cell pellet was resuspended in BSA buffer for total cell count, viability assessment, and cytospin spinning. Cell counting, cytospin storage, and expression of BAL results were identical to that described for induced sputum.

BIOPSY PROCESSING AND CELL QUANTIFICATION The biopsy specimens were embedded in Tissue Tek (Bayer Corporation, Elkhart, Indiana, USA) and snap frozen in liquid isopentane $\left(-80^{\circ} \mathrm{C}\right)$. Samples were stored at $-80^{\circ} \mathrm{C}$ until further processing. Frozen biopsy specimens were cut serially and divided in series of 19 sections ( $4 \mu \mathrm{m}$ thickness) and stored at $-20^{\circ} \mathrm{C}$ until required. Selection of morphologically optimal tissue was based on a haematoxylin and eosin (HE) stained slide. Tissue slides were air dried for 20 minutes and fixed in acetone for 10 minutes before staining. Immunohistochemical staining was performed with monoclonal antibodies against CD3 and CD4 (Becton-Dickinson, San Jose, USA), CD8 (mouse monoclonal antibody of own laboratory), CD68 (Dako, Copenhagen, Denmark), secreted form of eosinophil cationic protein (EG2) (Sanbio, Uden, The Netherlands), neutrophil elastase NP57 (Dako), and mast cell tryptase AA1 (Dako). Labelling of first antibodies was performed by biotinylated rabbit anti-mouse immunoglobulin antiserum and subsequently streptavidin conjugated to horseradish peroxidase. Amino-ethyl carbazole (AEC) was used as a chromogen, providing a reddish brown reaction product. Hydrogen peroxide was used for blocking of endogenous peroxidase and haematoxylin was used as a counterstain. For each antibody the number of positively stained cells was counted in a zone of $100 \mu \mathrm{m}$ deep below a randomly selected area of $1 \mathrm{~mm}$ of epithelial basement membrane. Slides were coded and counted by one observer in a blinded fashion. Light microscopy was performed using a Zeiss microscope at a magnification of $200 \times$ for the quantification of EG2 and AA1 and $400 \times$ for CD3, CD4, CD8, CD68, and NP57 positive cells. The thickness of the basement membrane was measured in HE stained slides using video assisted image analysis (Leica). The distance from the base of 


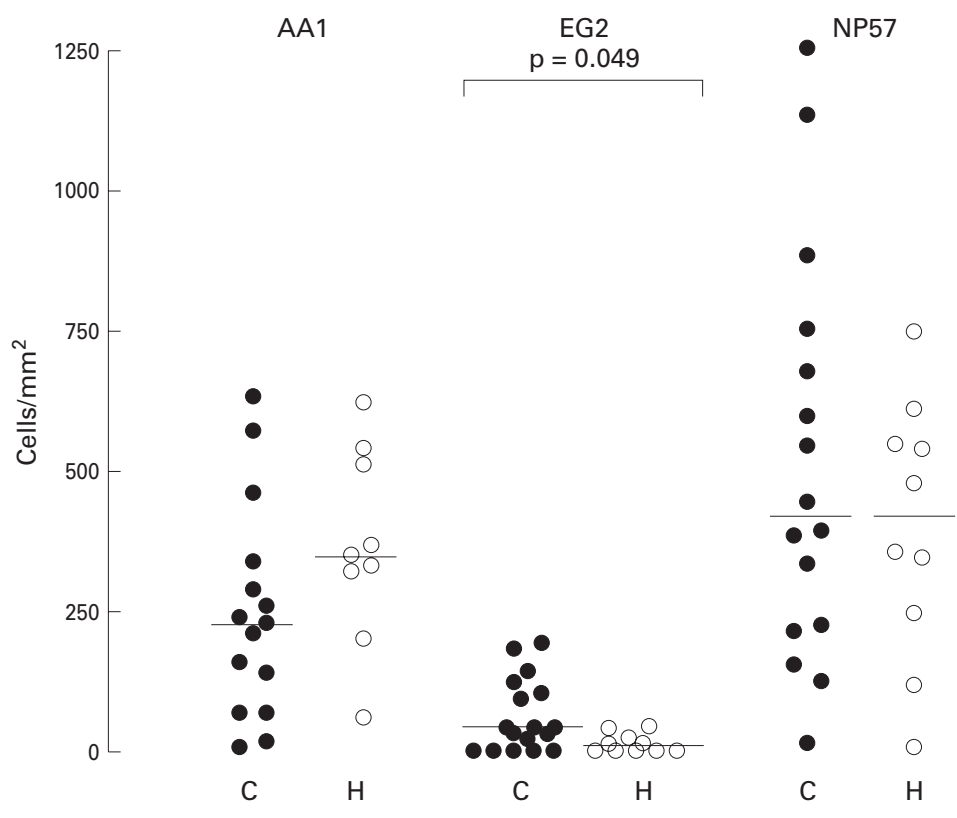

Figure 2 Mucosal mast cell, eosinophil and neutrophil counts in biopsy specimens from subjects with $C O P D(C, \bullet)$ and healthy individuals $(H, \circ)$. AA1 represents mast cells, EG2 eosinophils, and NP57 neutrophils.

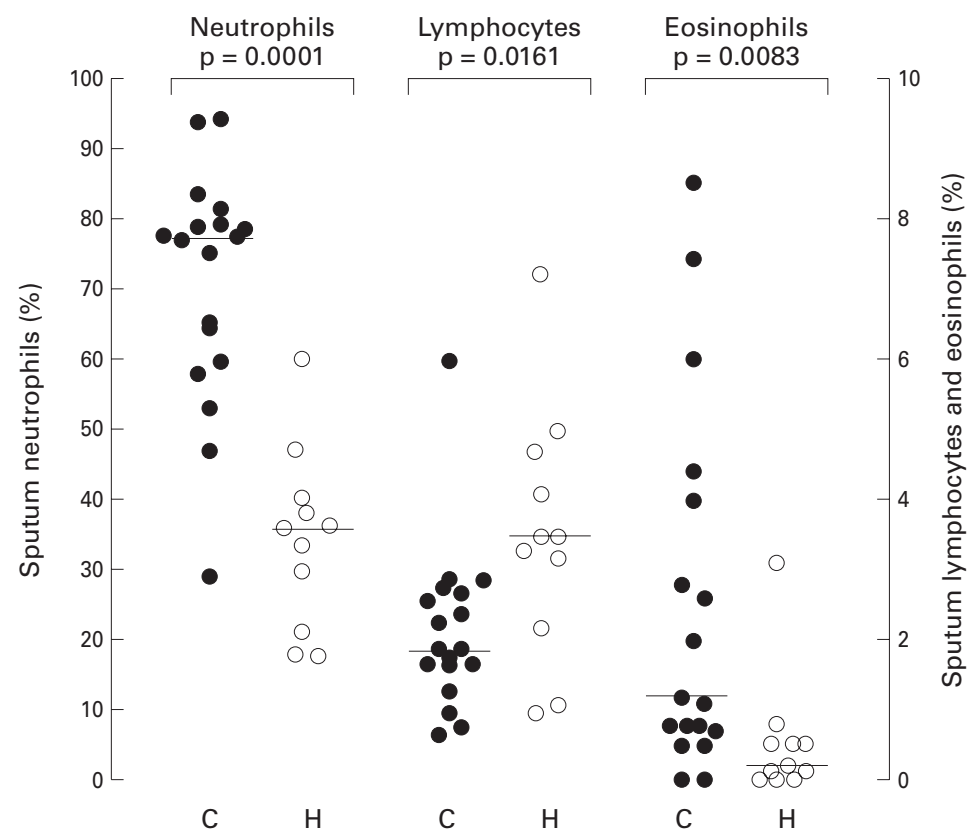

Figure 3 Differential cell counts in sputum from subjects with $C O P D(C, \bullet)$ and healthy individuals $(\mathrm{H}, \mathrm{O})$. Values are expressed as percentages of the total number of non-squamous cells. using AEC as a reagent giving a reddish brown staining. Haematoxylin was used as counterstain.

\section{BIOCHEMICAL ASSAYS}

The concentration of eosinophilic cationic protein (ECP) in sputum supernatant and BAL fluid was measured using the fluoroenzyme immunoassay ImmunoCAP ECP, kindly provided by Pharmacia, Uppsala, Sweden. Interleukin 8 (IL-8) was measured using the (h)IL-8 ELISA kit from Amersham, Little Chalfont, UK.

\section{ANALYSIS OF DATA}

Clinical characteristics are presented as mean (SD) unless stated otherwise; cell and mediator characteristics as medians with ranges. Differences between subjects with COPD and healthy subjects and within the COPD group were tested with the Mann-Whitney U test, and differences between subjects with COPD and healthy subjects in intracellular IL-8 staining were tested with the $\chi^{2}$ test. Correlation between cell variables was analysed using the Spearman's rank correlation coefficient. Differential sputum and BAL fluid cell counts were expressed as percentages of non-squamous cells. A $p$ value of $<0.05$ was considered statistically significant.

\section{Results}

SUBJECTS

Two subjects with COPD did not yield sufficient BAL fluid and biopsies for differential cell counting and were excluded from the analyses. One healthy subject was unwilling to undergo bronchoscopy. The clinical characteristics of the remaining 29 subjects are listed in table 1. Two subjects with COPD had cytospins in BAL fluid of too low quality for differential cell counting. One other subject with COPD and one healthy subject had biopsy specimens of too low quality for cellular counting.

COMPARISON BETWEEN PATIENTS WITH COPD AND HEALTHY SUBJECTS

The significant differences in cellular parameters between patients with COPD and healthy subjects are presented in table 2 . The most significant differences were found in sputum parameters.

the epithelium to the outer limit of the reticular layer was measured. The mean value of 20 measurements, performed at $100 \mu \mathrm{m}$ intervals in a morphological optimal area, was used for analysis.

SPUTUM AND BAL FLUID IMMUNOCYTOSTAINING Sputum and BAL fluid cytospins were stained with a monoclonal antibody against intracellular IL-8 (Boehringer Ingelheim, Ingelheim, Germany). Cytospins were incubated with saponin before the first and second antibody. A goat anti-rabbit antibody conjugated to peroxidase (1:400 dilution) was used as a second step. The peroxidase reaction was performed

\section{BIOPSY SPECIMENS}

The numbers of inflammatory cells in the mucosa of individual patients and controls are shown in figs 1 and 2. Numbers of EG2+ and CD68+ were significantly higher and numbers of CD3+ and CD4+ cells tended to be higher in subjects with COPD than in healthy subjects (table 2). CD4/CD8 ratios and thickness of the reticular basement membrane did not differ between subjects with COPD and healthy individuals $(1.30 \quad(0.22-5.00)$ versus 1.08 (0.36-2.10), $\mathrm{p}=0.35$; and 13.5 (7.6-20.8) versus $11.1(7.9-18.6) \mu \mathrm{m}, \mathrm{p}=0.11$, respectively). 


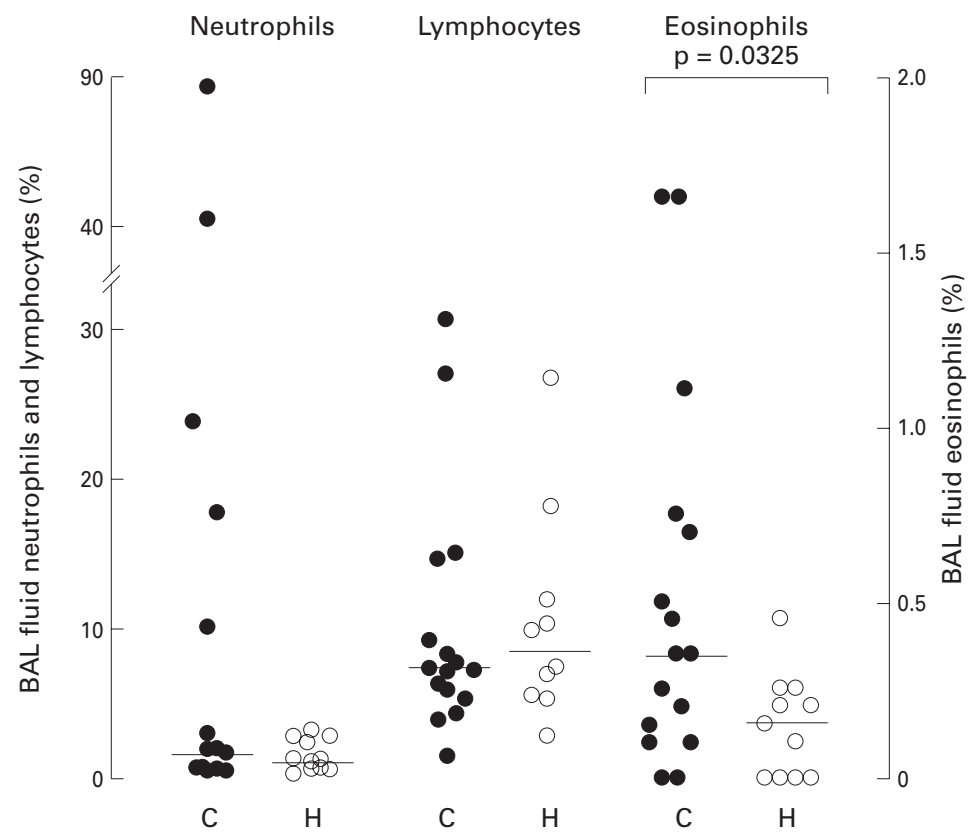

Figure 4 Differential cell counts in bronchoalveolar lavage (BAL) fluid from subjects with $C O P D(C, \bullet)$ and healthy individuals $(H, O)$.

SPUTUM

The percentages of inflammatory cells in the sputum are shown in fig 3. Subjects with COPD had significantly higher percentages of neutrophils and eosinophils (table 2); they had significantly lower percentages but similar total numbers of macrophages and lymphocytes.

BAL FLUID

The percentages of inflammatory cells in the BAL fluid are shown in fig 4 . The percentage of eosinophils was significantly higher in subjects with COPD than in healthy subjects (table 2). No other significant differences were found.

IL-8 AND ECP

Intracellular IL-8+ cells in sputum and BAL fluid were observed in 12 out of 18 and four out of 16 subjects with COPD, and in eight out of 11 and two out of 11 healthy subjects, respectively, which is not statistically different. Neutrophils and macrophages were the predominant IL-8+ cell type in 10 and two subjects with COPD and four and one healthy subjects, respectively. Non-squamous epithelial cells were the predominant IL- $8+$ cell type in three healthy subjects. IL-8 in sputum supernatant was significantly higher in subjects with COPD than in healthy subjects with the same trend in BAL fluid (table 2). ECP in sputum supernatant was significantly higher in subjects with COPD than in healthy subjects (table 2) and was detectable in BAL fluid in only seven subjects with COPD (median 12 (4-62) ng/ml in these seven) and not in healthy subjects. When ECP was expressed per eosinophil the difference in sputum between subjects with COPD and healthy subjects disappeared (15.1 $(5.8-43.3)$ versus $17.2(3.8-119.0) \mathrm{ng} / \mathrm{ml}, \mathrm{p}=$ $0.48)$.

ANALYSIS WITHIN COPD

After assessing which inflammatory parameters differed significantly between COPD patients and healthy subjects we compared groups of COPD patients with values of inflammatory parameters within and out of the range of those found in healthy subjects. Significant differences in clinical and inflammatory parameters between these groups are shown in table 3.

Subjects with COPD with more mucosal EG2+ cells $\left(>40\right.$ cells $\left./ \mathrm{mm}^{2}\right)$ than healthy subjects had significantly more mucosal CD4+ cells than the other subjects with COPD (table 3). Subjects with COPD with more sputum eosinophils $(>3.1 \%)$ than healthy subjects had a significantly lower $\mathrm{FEV}_{1} / \mathrm{VC}$, more serum eosinophils, higher sputum ECP, but less sputum ECP per eosinophil than the other subjects with COPD (table 3). The percentage of sputum eosinophils correlated with $\mathrm{FEV}_{1} / \mathrm{VC}($ rho $=-0.56, \mathrm{p}=0.016)$.

Fourteen of the 18 subjects with COPD had more sputum ECP than healthy subjects $(>218 \mathrm{ng} / \mathrm{ml})$. They did not differ in clinical and inflammatory parameters from the four subjects with COPD with sputum ECP values in the normal range. Subjects with COPD with more eosinophils in BAL fluid $(>0.45 \%)$ than healthy subjects had more mucosal NP57+ cells than the other subjects with COPD (table 3). Subjects with COPD with more mucosal CD68+ cells $\left(>1580\right.$ cells $\left./ \mathrm{mm}^{2}\right)$ than healthy subjects had significantly more mucosal CD4+ cells than the other subjects with COPD (table 3). The number of mucosal CD68+ cells correlated with the number of mucosal CD4+ cells (rho $=0.55, \mathrm{p}=0.026)$.

Table 3 Significant differences between groups of COPD with values within and out of the range of healthy subjects for parameters that differ significantly between COPD and healthy subjects

\begin{tabular}{|c|c|c|c|c|c|c|c|c|}
\hline \multirow{2}{*}{\multicolumn{3}{|c|}{$\begin{array}{l}\text { Differences between COPD and healthy subjects } \\
\text { Upper limit of ranget }\end{array}$}} & \multirow{3}{*}{$\begin{array}{l}\text { Difference between groups } \\
\text { of COPD } \\
\mathrm{CD} 4+\left(\text { cells } / \mathrm{mm}^{2}\right)\end{array}$} & \multicolumn{2}{|c|}{ COPD out of range of healthy } & \multicolumn{2}{|c|}{ COPD within range of healthy } & \multirow{3}{*}{$\frac{p \text { value }}{0.03}$} \\
\hline & & & & \multirow{2}{*}{$\begin{array}{l}\text { Median (ranges) } \\
930(560-1320)\end{array}$} & \multirow{2}{*}{$\frac{n}{6}$} & \multirow{2}{*}{$\begin{array}{l}\text { Median (ranges) } \\
210(100-1300)\end{array}$} & \multirow{2}{*}{$\begin{array}{l}n \\
12\end{array}$} & \\
\hline Eosinophils & Biopsy & $>40$ cells $/ \mathrm{mm}^{2}$ & & & & & & \\
\hline & Sputum & $>3.1 \%$ & $\mathrm{FEV}_{1} / \mathrm{VC}(\%)$ & $41(34-58)$ & 5 & $53(38-67)$ & 13 & 0.027 \\
\hline & & & $\begin{array}{l}\text { Serum eosinophils } \\
\text { (cells } / \mathrm{ml} \text { ) }\end{array}$ & $420(240-540)$ & 5 & $130(30-350)$ & 13 & 0.002 \\
\hline & & & Sputum ECP (ng/ml) & $1834(1105-4530)$ & 5 & $332(115-23760)$ & 13 & 0.021 \\
\hline & & & Sputum & $9.4(5.9-15.1)$ & 5 & $35.5(5.8-43.4)$ & 13 & 0.037 \\
\hline & & & ECP/eosinophils (ng/ml) & & & & & \\
\hline & BAL & $>0.45 \%$ & $\mathrm{NP} 57+\left(\right.$ cells $\left./ \mathrm{mm}^{2}\right)$ & $220(120-590)$ & 6 & $670(10-1250)$ & 10 & 0.034 \\
\hline \multirow{4}{*}{$\begin{array}{l}\text { Macrophages } \\
\text { Neutrophils }\end{array}$} & Biopsy & $>1580$ cells $/ \mathrm{mm}^{2}$ & $\mathrm{CD} 4+\left(\right.$ cells $\left./ \mathrm{mm}^{2}\right)$ & $1220(530-1320)$ & 5 & $335(100-960)$ & 13 & 0.015 \\
\hline & Sputum & $>60 \%$ & Sputum IL-8 (pg/ml) & $23(4-1300)$ & 13 & $7(4-17)$ & 5 & 0.027 \\
\hline & & & Sputum ECP (ng/ml) & $1510(274-23760)$ & 13 & $250(115-1105)$ & 5 & 0.012 \\
\hline & & & $\begin{array}{l}\text { Sputum epithelial cells } \\
(\%)\end{array}$ & $0(0-1.1)$ & 13 & $1.4(0.5-2.8)$ & 5 & 0.001 \\
\hline
\end{tabular}


Subjects with COPD with more sputum neutrophils $(>60 \%)$ than healthy subjects had significantly more sputum IL- 8 and ECP and more sputum non-squamous epithelial cells than the other subjects with COPD (table 3 ). They did not have more ECP per eosinophil in sputum (21.6 (5.9-41.5) versus 15.1 (5.843.3) $\mathrm{ng} / \mathrm{ml}, \mathrm{p}=0.9)$.

\section{Discussion}

We found that subjects with COPD who do not currently smoke have airways inflammation as shown by a significant increase in mucosal macrophage and eosinophil numbers, sputum neutrophil and eosinophil percentages, and BAL fluid eosinophil percentages compared with healthy controls. The number of CD3+ and CD4+ T cells in the mucosa tended to be increased and CD4/CD 8 ratios were similar to those of healthy controls. Eosinophils did not seem to be activated since the concentration of ECP expressed per eosinophil did not differ between subjects with COPD and healthy individuals.

We investigated which factors discriminate COPD patients with cellular and mediator values out of the range found in healthy controls from the remaining patients with COPD. Patients with higher numbers of mucosal macrophages than healthy controls had higher numbers of CD4+ cells than the remaining patients with COPD. Those with eosinophilia in biopsy specimens also had higher numbers of mucosal CD4+ cells, those with sputum eosinophilia had lower $\mathrm{FEV}_{1} / \mathrm{VC}$ ratios, whereas BAL eosinophilia was accompanied by more neutrophils in mucosal biopsy specimens.

To the best of our knowledge, this is the first reported study in which bronchial biopsy specimens of subjects with COPD with fixed airway obstruction who were not currently smoking have been formally compared with those of healthy subjects. We found that inflammation is not only present in the airway wall of smokers with COPD $^{9}{ }^{10}$ but also in those not currently smoking. In contrast to O'Shaughnessy et al and Saetta et al, ${ }^{10}$ we did not find a predominance of CD8+ over CD4+ cells in the mucosa. These differences are probably due to the fact that we studied subjects with COPD who were not current smokers, whereas they studied current smokers. Current smoking has been shown to affect $\mathrm{T}$ cell subset proportions in healthy subjects and increased numbers of CD8+ cells in the blood of heavy smokers returned to lower values after smoking was stopped. ${ }^{18}{ }^{19}$ Similarly, current smoking itself may affect $T$ cell subsets in the airway wall and cause a predominance of CD8+ cells. We speculate that CD8+ cells are important in causing acute tissue damage via the release of lytic substances such as perforin and granzyme. ${ }^{22}$ After cessation of smoking chronic ongoing inflammation persists, as has been shown in our obstructed patients with COPD and in a group of obstructed and nonobstructed patients with chronic bronchitis. ${ }^{23}$ CD8 + T cells have a less prominent role in this ongoing inflammation which may cause chronic tissue damage via insult of the extracellular matrix or via release of mediators that interfere with normal tissue repair. ${ }^{24}{ }^{25}$

Increase of mucosal macrophages has been a consistent finding in current smokers in COPD $^{5-10}$ and this was also found in our study. Macrophages are known to participate in elimination of foreign antigens and injured tissue and they normally stay in lung tissue for only days to months. ${ }^{24}$ It is also possible that they play a central role in the ongoing inflammation via recruitment and activation of other inflammatory cells and via interference with normal tissue repair. Longitudinal studies investigating macrophage activity in biopsy specimens and clinical parameters before and after smoking cessation may give information about the role of these cells in COPD.

Subjects with COPD had significantly higher numbers of eosinophils in the airways but these were probably not activated cells. This is suggested by the fact that the concentration of their activation product ECP, when expressed as concentration per eosinophil, was not different from that of healthy subjects. Moreover, recent data suggest that the presence of EG2 on mucosal eosinophils does not necessarily mean that these cells are activated. It is our opinion that the higher number of eosinophils in our patients in a stable phase of their disease is most probably caused by non-specific recruitment as part of the ongoing inflammation of the airways mentioned above. Adhesion molecules which play a role in leucocyte recruitment such as VCAM-1 or ICAM- ${ }^{26}$ may be upregulated in COPD as part of ongoing inflammation and thereby cause increased tissue entry of eosinophils. The findings of Lacoste et al support our results in that they found increased numbers of eosinophils in the airway wall which were not degranulated and thus not activated. ${ }^{4}$

The association of increased numbers of mucosal macrophages and CD4+ T cells may imply that the latter cells have a role in ongoing airway inflammation in COPD as well. CD4+ cells can cause tissue destruction by interference with normal tissue repair after smoking. They can produce a variety of cytokines and thereby regulate recruitment, differentiation, and activation of inflammatory cells. ${ }^{25}$ In this respect future studies have to assess whether CD4+ cells do have a central role in the regulation of airway remodelling. The association of increased numbers of EG2+ cells with increased numbers of CD4+ cells probably reflects their common mechanism of recruitment.

It is remarkable that eosinophil numbers and percentages in sputum, BAL fluid, and biopsy specimens are increased in COPD and it is difficult to explain why only sputum eosinophilia is associated with airway obstruction. Sputum represents cells from the lumen of the central airways whereas airway obstruction occurs mainly in the peripheral airways. The association found may be due to both eosinophilia and airway obstruction being the result of ongoing airway inflammation. Accumulation of eosinophils may be most prominent in the 
lumen of the central airways, whereas they rapidly pass alveoli and peripheral airways as central airways may serve as an important outlet from the lungs for inflammatory cells. This would explain why an association was found with eosinophils in sputum and not in biopsy specimens or BAL fluid.

Our study extends the findings of Lusuardi $e t$ $a l^{27}$ who investigated inflammatory markers in BAL fluid in never smokers with obstructive chronic bronchitis. They reported increased numbers of neutrophils compared with healthy controls. We did not find increased numbers of neutrophils in the BAL fluid, possibly because not all our subjects had chronic bronchitis or because they had less sputum production. ${ }^{28}$ Lams et al investigated inflammatory changes in the small airways submucosa of smokers and non-smokers with or without COPD ${ }^{29}$ and did not find a difference between subjects with and without airflow obstruction in this compartment of the airways. Analysis of non-smokers only might have shown differences in inflammatory cells between subjects with and without airflow obstruction.

We tried very carefully to exclude subjects with asthma in order to study airway inflammation of COPD as well as possible. We excluded subjects with a history of asthma or atopy, tested atopy both with a skin prick test and Phadiatop, and selected only subjects with fixed bronchoconstriction. We are confident that our subjects did not have asthma since the thicknesses of the epithelial basement membrane of subjects with COPD and healthy subjects were in the same range. A trend towards thicker basement membranes was observed in COPD, but this has also been observed by other investigators studying non-asthmatic subjects with COPD. ${ }^{4}$

We conclude that inflammatory changes are observed in the airways of subjects with COPD who do not currently smoke. These changes include increased numbers of mucosal macrophages and sputum neutrophils. Numbers and percentages of eosinophils are increased in mucosa, sputum and BAL fluid, but these cells do not appear to be active and may be bystanders of ongoing inflammation. CD4/ CD8 ratios were not increased in COPD, which suggests that the predominance of CD8+ cells found by other investigators might have been the result of current smoking by their subjects. The increase in mucosal eosinophils and macrophages is associated with an increase in mucosal CD4+ cells and a decrease in mucosal neutrophils and with airflow obstruction. This may imply that CD4+ cells have a role in tissue remodelling or in modulating inflammatory cell number and activity. Further studies on the role of $\mathrm{T}$ lymphocytes and macrophages in the ongoing airway inflammation in COPD are needed and should take into account the acute effect of smoking.

This study was supported by the Stichting Astma Bestrijding and Astra Pharmaceutica BV, The Netherlands. The authors thank Dr Nikos Tzanakis for his help with the bronchoscopies; Andre Timmermans, Jacobien Noordhoek, and Hein Lange for the processing and counting of the sputum and BAL fluid; Henk Meekers for help with the intracellular IL-8 measurements; and Bea Rutgers and Monique Lodewijk for the cutting and staining of the biopsy samples.

1 Siafakas NM, Vermeire P, Pride NB, et al. Optimal assessment and management of chronic obstructive pulmonary disease (COPD). The European Respiratory Society Task Force. Eur Respir f 1995;8:1398-420.

2 Jeffery PK. Comparative morphology of the airways in asthma and chronic obstructive pulmonary disease. Am $\mathcal{F}$ Respir Crit Care Med 1994;150:S6-13.

3 Saetta M, Finkelstein R, Cosio MG. Morphological and cellular basis for airflow limitation in smokers. Eur Respir $\mathcal{F}$ 1994;7:1505-15.

4 Lacoste JYL, Bousquet J, Chanez P, et al. Eosinophilic and neutrophilic inflammation in asthma, chronic bronchitis, and chronic obstructive pulmonary disease. 7 Allergy Clin Immunol 1993;92:537-48.

5 Saetta MP, Di Stefano A, Maestrelli P, et al. Activated T-lymphocytes and macrophages in bronchial mucosa of subjects with chronic bronchitis. Am Rev Respir Dis 1993;147:301-6.

6 Maestrelli P, Saetta M, Di Stefano A, et al. Comparison of leukocyte counts in sputum, bronchial biopsies, and leukocyte counts in sputum, bronchial biopsies, and 1995;152:1926-31

7 Mueller R, Chanez P, Campbell AM, et al. Different cytokine patterns in bronchial biopsies in asthma and chronic bronchitis. Respir Med 1996;90:79-85.

8 Di Stefano A, Turato G, Maestrelli P, et al. Airflow limitation in chronic bronchitis is associated with T-lymphocyte and macrophage infiltration of the bronchial mucosa. Am f Respir Crit Care Med 1996;153:629-32.

9 O'Shaughnessy TC, Ansari TW, Barnes NC, et al. Inflammation in bronchial biopsies of subjects with chronic bronchitis: inverse relationship of CD8+ T lymphocytes with $\mathrm{FEV}_{1}$. Am $\mathcal{F}$ Respir Crit Care Med 1997;155:852-7.

10 Saetta M, Di Stefano A, Turato G, et al. CD8+ T-lymphocytes in peripheral airways of smokers with chronic obstructive pulmonary disease. Am $₹$ Respir Crit Care Med 1998;157:822-6.

11 Saetta M, Di Stefano A, Maestrelli P, et al. Airway eosinophilia in chronic bronchitis during exacerbations. Am 7 Respir Crit Care Med 1994;150:1646-52.

12 Pesci A, Rossi GA, Bertorelli G, et al. Mast cells in the airway lumen and bronchial mucosa of patients with chronic bronchitis. Am f Respir Crit. Care Med 1994;149:1311-6.

13 Sibille Y. Pulmonary immune cells in health and disease: polymorphonuclear neutrophils. Eur Respir F 1993;6:152943.

14 Turnbull LS. Mediators of immediate-type hypersensitivity in sputum from patients with chronic bronchitis and asthma. Lancet 1977;ii:526-9.

15 Keatings V, Jatakanon A, Miin Worsdell Y, et al. Effects of inhaled and oral glucocorticoids on inflammatory indices in asthma and COPD. Am 7 Respir Crit Care Med 1997;155:542-8.

16 Baggiolini M, Walz A, Kunkel SL. Neutrophil-activating peptide-1/interleukin 8 , a novel cytokine that activates neutrophils. F Clin Invest 1989;84:1045-9.

17 Burke WMJ, Roberts CM, Bryant DH, et al. SmokingBurke WMJ, Roberts CM, Bryant $\mathrm{DH}$, et al. Smoking-
induced changes in epithelial lining fluid volume, cell deninduced changes in epithelial lining fluid vol
sity and protein. Eur Respir $\mathcal{F}$ 1992;5:780-4.

18 Hughes DA, Haslam PL, Townsend PJ, et al. Numerical and functional alterations in circulatory lymphocytes in cigarette smokers. Clin Exp Immunol 1985;61:459-66.

19 Miller LG, Goldstein G, Murphy M, et al. Reversible alterations in immunoregulatory $\mathrm{T}$ cells in smoking. Analysis by monoclonal antibodies and flow cytometry. Chest 1982;82: 526-9.

20 American Thoracic Society. Standards for the diagnosis and care of patients with chronic obstructive pulmonary disease (COPD) and asthma. Am Rev Respir Dis 1987;136:225-44.

21 Quanjer PH, Tammeling GJ, Cotes JE, et al. Lung volumes and forced ventilatory flows. Eur Respir F 1993;6:5-40.

22 Garcia Sanz JA, Velotti F, MacDonald HR, et al. Appearance of granule-associated molecules during activa-
tion of cytolytic T-lymphocyte precursors by defined stimuli. Immunology 1988;64:129-34.

23 Turato G, Di Stefano A, Maestrelli P, et al. Effect of smoking cessation on airway inflammation in chronic bronchitis. Am 7 Respir Crit Care Med 1995;152:1262-7.

24 Sibille Y. Macrophages and polymorphonuclear neutrophils in lung defense and injury. Am Rev Respir Dis 1990;141: in lung defer

25 Agostini C. Pulmonary immune cells in health and disease: lymphocytes. Eur Respir f 1993;6:1378-401

26 Pilewski JM, Albelda SM. Adhesion molecules in the lung. An overview. Am Rev Respir Dis 1993;148:S31-7.

27 Lusuardi M, Capelli A, Cerutti CG, et al. Airways inflammation in subjects with chronic bronchitis who have never smoked. Thorax 1994;49:1211-6.

28 Thompson AB, Daughton D, Robbins RA, et al. Intraluminal airway inflammation in chronic bronchitis. Characterization and correlation with clinical parameters. Am Rev Respir Dis 1989;140:1527-37.

29 Lams BEA, Sousa AR, Rees PJ, et al. Immunopathology of the small-airway submucosa in smokers with and whithout chronic obstructive pulmonary disease. Am $\mathcal{F}$ Respir Crit Care Med 1998;158:1518-23.
Caronic obstructive pulmonary 